\title{
Hawaii-Aleutian Daylight Time
}

National Cancer Institute

\section{Source}

National Cancer Institute. Hawail-Aleutian Daylight Time. NCI Thesaurus. Code C116262.

Local daylight-savings time, based at the 150th meridian west of the Greenwich

Observatory, established as nine hours behind Coordinated Universal T ime. 